\title{
Elevated lactate dehydrogenase and D-dimer levels as a sign of aortic dissection
}

\author{
(D) Marina Vučijak- \\ Grgurević1*, \\ (D)Edin Begić², \\ (D)Azra Durak- \\ Nalbantićc \\ (D)Faris Zvizdić'
}

${ }^{1}$ Clinical Center University of Sarajevo, Sarajevo, Bosnia and Herzegovina

${ }^{2}$ General Hospital "Prim. dr.Abdulah Nakaš", Sarajevo, Bosnia and Herzegovina
RECEIVED:

November 10, 2020

ACCEPTED:

December 18, 2020

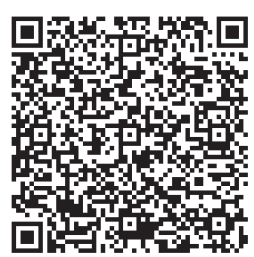

KEYWORDS: aortic dissection, lactate dehydrogenase. D-dimer.

CITATION: Cardiol Croat. 2021;16(1-2):83. | https://doi.org/10.15836/ccar2021.83

*ADDRESS FOR CORRESPONDENCE: Marina Vučijak-Grgurević, Clinical Center University of Sarajevo, Bolnička 25, 71000 Sarajevo, Bosnia and Herzegovina. / E-mail: marina.vucijak@gmail.com

ORCID: Marina Vučijak-Grgurević, https://orcid.org/0000-0002-3755-0968 • Edin Begić, https://orcid.org/0000-0001-6842-262X Azra Durak-Nalbantić, https://orcid.org/0000-0002-5175-8941 • Faris Zvizdić, https://orcid.org/0000-0001-7647-2723

|IIIIIIIIIIIIIIIIIIIIIIIIIIIIIIIIIIIIIIIIIIIIIIIIIIIIIIIIIIIIIIIIIIIIIIIIIIIIIIIIIIIIIIIIIIIIIIIIIIIIIIIIIIIIIIIIII

Case report: 39-years-old male patient was admitted to Clinic for Cardiology due to high blood pressure $(180 / 105 \mathrm{mmHg})$ and epigastric pain which started 24 hours before. Patient was also febrile, he denied previous history of high blood pressure and had a hepatitis B (received blood transfusion during the war time). He is smoker and a heavy manual worker on the road. On electrocardiogram (ECG) there were signs of left ventricular hypertrophy. On the chest X-ray there were no signs of heart and large vessels enlargement and no lung infiltration. On echocardiography mild left ventricular hypertrophy were found, while all other parameters, including dimension of ascending aorta were normal. In laboratory results aspartate aminotransferase (AST) was $105 \mathrm{IU} / \mathrm{mL}$, alanine aminotransferase (ALT) was $88 \mathrm{IU} / \mathrm{mL}$, creatine kinase (CK) was $584 \mathrm{IU} / \mathrm{mL}$, lactate dehydrogenase (LDH) was $1232 \mathrm{IU} / \mathrm{mL}$, while high-sensitive cardiac troponin T was within normal limits. Patient had high C-reactive protein (CRP) $79 \mathrm{mg} / \mathrm{L}$, increased leukocytes $12.0 \times 10^{9} / \mathrm{L}$, high D-dimer $4.37 \mu \mathrm{g} / \mathrm{mL}$ and low platelets count 99x109/L. Two days after levels of AST, ALT and CK normalized, LDH was lower but still elevated (999 IU/mL), while D-dimer raised $(4.74 \mu \mathrm{g} / \mathrm{mL})$ as well as CRP (180 mg/L) although antibiotics were administrated: first cefazolin and after ciprofloxacin and clarithromycin. Because high D-dimer and persistently elevated LDH patient was sent to perform computed tomography (CT) of thorax due to high clinical suspicion of pulmonary thromboembolism. CT scan result was completely unexpected: aortic dissection of descending aorta (Stanford type B) with normal dimension of aorta. Next day thoracic endovascular aortic repair (TEVAR) was performed. During further hospitalization the patient as electrically and hemodynamically stable. During a three-year follow-up, a patient without new acute cardiovascular incidents.

Conclusion: Aortic dissection is life-threatening condition whose late diagnosis is main reason for high mortality. Combination of high LDH (marker of tissue necrosis) and high D-dimer could be a clue to the early diagnosis of aortic dissection. ${ }^{1}$

LITERATURE IIIIIIIIIIIIIIIIIIIIIIIIIIIIIIIIIIIIIIIIIIIIIIIIIIIIIIIIIIIIIIIIIIIIIIIIIIIIIIIIIIIIIIIIIIIIIIIIIII

1. He H, Chai X, Zhou Y, Pan X, Yang G. Association of Lactate Dehydrogenase with In-Hospital Mortality in Patients with Acute Aortic Dissection: A Retrospective Observational Study. Int J Hypertens. 2020 January 7;2020:1347165. https://doi.org/10.1155/2020/1347165 